\title{
Pengaruh Pembelajaran Berpendekatan Saintifik Berorientasi (CIRC) Terhadap Hasil Belajar Bahasa Indonesia dengan Kovariabel Kemampuan Verbal
}

\author{
Ni Putu Winda Purnamayani ${ }^{1}$, Nyoman Dantes ${ }^{2}$, Kadek Yudiana ${ }^{3}$ \\ ${ }^{13}$ Prodi Pendidikan Guru Sekolah Dasar, FIP \\ ${ }^{2}$ Prodi Bimbingan Konseling, Flp \\ Universitas Pendidikan Ganesha \\ Singaraja, Indonesia \\ e-mail: niputuwinda543@gmail.com ${ }^{1}$,dantes@undiksha.ac.id², \\ kadek.yudiana@undiksha.ac.id ${ }^{3}$
}

\begin{abstract}
Abstrak
Penelitian ini bertujuan untuk mengetahui: (1) pengaruh pembelajaran berpendekatan saintifik berorientasi Cooperative, Integrated, Reading, And Composition (CIRC) terhadap hasil belajar bahasa Indonesia, (2) pengaruh pembelajaran berpendekatan saintifik berorientasi Cooperative, Integrated, Reading, And Composition (CIRC) terhadap hasil belajar bahasa Indonesia setelah kemampuan verbal dikendalikan, dan (3) besarnya kontribusi kemampuan verbal terhadap hasil belajar bahasa Indonesia pada siswa kelas $\mathrm{V}$ di gugus I kecamatan jembrana. Jenis penelitian ini adalah kuasi-eksperimental, dengan desain posstest only control group design. Populasi penelitian ini adalah seluruh siswa kelas V SD Gugus I Kecamatan Jembrana yang berjumlah 162 orang. Sampel ditarik dengan teknik random sampling. Sampel dalam penelitian ini adalah berjumlah 41 siswa. Data hasil belajar Bahasa Indonesia dan kemampuan verbal dikumpulkan dengan metode tes. Data dianalaisis dengan menggunakan ANAKOVA. Hasil penelitian menunjukkan bahwa: (1) terdapat perbedaan yang signifikan hasil belajar bahasa Indonesia siswa yang mengikuti model pembelajaran CIRC dengan siswa yang mengikut pembelajaran konvensional $(\mathrm{Sig}=0,001<0,05)$, (2) terdapat perbedaan yang signifikan hasil belajar bahasa Indonesia siswa dengan kovariabel kemampuan verbal dikendalikan ( $\mathrm{Sig}=0.046<0,05)$, (3) terdapat kontribusi kemampuan verbal terhadap hasil belajar bahasa Indonesia siswa dengan besarya kontibusi yaitu $48,7 \%$.
\end{abstract}

Kata-kata kunci: berpendekatan saintifik, (CIRC), kemampuan verbal

\begin{abstract}
This research was aimed to know: (1) the effect of scientific approach oriented by Cooperative, Integrated, Reading, And Composition (CIRC) on students' learning outcomes of Indonesian, (2) the effect of scientific approach oriented by Cooperative, Integrated, Reading, And Composition (CIRC) on students' learning outcomes of Indonesian after students' verbal ability was controlled, (3) the contribution of students' verbal ability on students' learning outcomes of Indonesian of students of grade $V$ in group I Jembrana sub-district. The research was a quasi-experimental research with posttest only control group design. The population of this research was 162 fifth grade students in Gugus I Kecamatan Jemabrana. By pulled out random sampling technique, 41 students were chosen as a sample in this research. The data of students' learning outcomes of Indonesian and students' verbal ability was collected by test. The collected data was analyzed by using ANACOVA. The result of the data analyzed showed that: (1) there was the significance different of students' learning outcomes of Indonesian of students who were taught by using scientific approach oriented by Cooperative, Integrated, Reading, And Composition (CIRC) and who were taught by using conventional learning (Sig $=0.001<0.05$ ), (2) there was the significance different of students' learning outcomes of Indonesian after the students' with verbal ability was controlled (Sig $=0.046<0.05$ ), (3) there was contribution of students' verbal ability on students' learning outcomes of Indonesian with the amount of $48.7 \%$.
\end{abstract}

Keywords: scientific approach, (CIRC), verbal ability 


\section{Pendahuluan}

Salah satu pendidikan formal di sekolah dasar adalah pembelajaran bahasa. Pembelajaran bahasa menjadi sangat penting karena fungsi bahasa yang merupakan alat komunikasi yang bersifat universal. Pembelajaran Bahasa Indonesia merupakan pembelajaran yang kompleks dengan mengutamakan aspek keterampilan berbahasa, yaitu keterampilan menyimak, keterampilan berbicara, keterampilan membaca dan keterampilan menulis Tarigan (dalam Tristiantari, 2016)

Pembelajaran bahasa di SD yang penyajian bahasa terpisah-pisah membuat siswa menjadi sulit dalam mencapai tujuan kompetensi yang diinginkan. Terpisah maksudnya guru mengajarkan bahasa secara terpisah, misalnya membaca diajarkan pada jam yang berbeda dengan menulis. Pada saat siswa ditugaskan membaca wacana atau teks dengan paragraf yang panjang siswa kesulitan untuk memahami pokok pikiran yang terdapat dalam paragraf tesebut. Saat berbicara siswa juga masih terkesan kaku dalam menyampaikan informasi atau pendapat serta dalam menulis karangan atau sebuah cerita siswa belum mengetahui penempatan tanda baca, huruf kapital pada kata atau kalimat yang sesuai EYD (ejaan bahasa Indonesia yang disempurnakan), sehingga hasil belajar bahasa Indonesia siswa cenderung rendah.

Bahasa merupakan salah satu alat komunikasi yang memiliki peran sentral dalam perkembangan intelektual, sosial, dan emosional peserta didik dan merupakan penunjang keberhasilan dalam mempelajari semua bidang studi. Pembelajaran bahasa diharapkan membantu peserta didik mengenal dirinya, budayanya, dan budaya orang lain. Selain itu, pembelajaran bahasa juga membantu peserta didik mampu mengemukakan gagasan dan perasaan, berpartisipasi dalam masyarakat, dan bahkan menemukan serta menggunakan kemampuan analitis dan imaginatif yang ada dalam dirinya (Dewi, 2013).

Satria dan Riqo WS (dalam Pradyani, 2014) menekankan bahwa salah satu yang mempengaruhi kemampuan bahasa adalah kemampuan verbal. Kemampuan verbal dalam hal ini hanya menyangkut dimensi intelektual yang merupakan kemampuan potensial yang dimiliki oleh siswa dalam melakukan konsep-konsep yang diungkapkan dalam bentuk kata-kata dan kemampuan untuk berpikir dengan menggunakan bahasa. Kemampuan verbal erat kaitannya dengan kecerdasan linguistik-verbal dimana siswa yang memiliki kebahasaan/linguistik yang tinggi akan lebih mudah mempelajari bahasa. Kemampuan untuk mengenali suatu kata, mengetahui dan memahami makna atau arti kata tersebut kemudian memahami hubungan suatu kata dengan kata-kata yang lain. Oleh karena itu kemampuan verbal ini berkaitan dengan bahasa, maka siswa yang berkemampuan verbal akan memiliki potensi yang besar untuk mencapai Hasil yang baik dalam pelajaran bahasa, termasuk bahasa Indonesia.

Faktor kemampuan verbal merupakan mengenali suatu kata, mengetahui dan memahami faktor yang sangat penting. Kemampuan verbal diartikan sebagai kemampuan untuk makna atau arti kata tersebut kemudian memahami fungsi dan penggunaan kata-kata tersebut serta memahami hubungan suatu kata dengan kata-kata yang lain. Jadi, intinya untuk memudahkan dalam menghadapi tes kemampuan vernal, yang dibutuhkan dan yang menentukan adalah perbendaharaan kata yang banyak.

Komunikasi verbal dilakukan dengan dua cara yaitu berbicara dan menulis, membaca dan mendengarkan. Berbicara pada umumnya lebih disukai dari pada menulis. Selain lebih praktis, berbicara juga dianggap lebih mudah karena langsung di dengar oleh pihak penerima informasi. Kemampuan verbal dapat mempengaruhi hasil belajar karena tanpa adanya kemampuan verbal yang baik maka hasil belajar kurang maksimal. Untuk memperoleh hasil belajar yang baik maka guru dan siswa harus memahami betul apa yang dimaksud dengan belajar.

Menurut Hamalik (dalam Susanto, 2013: 3) belajar merupakan suatu proses, suatu kegiatan, dan bukan merupakan suatu hasil atau tujuan. Dengan demikian, belajar belajar bukan sekedar mengingat atau menghafal, namun lebih luas. Adapun pengertian belajar menurut W.S. Winkel (dalam Susanto, 2013: 4) adalah suatu aktivitas mental yang berlangsung dalam interaksi aktif antara seseorang dengan lingkungan, dan menghasilkan perubahanperubahan dalam pengetahuan, pemahaman, keterampilan, dan nilai sikap yang relatif konstan dan berbekas. Pada hakikatnya belajar adalah suatu kegiatan individu untuk memperoleh pengetahuan, perilaku, dan keterampilan dengan cara mengolah bahan ajar, Dimyati (dalam Sugiartini, 2013) Hakikat dari aktivitas belajar adalah suatu perubahan yang terjadi dalam diri individu, Djaramah (dalam Sugiartini, 2013). 
Hasil belajar dapat dipengaruhi oleh dua faktor yang pertama dari dalam diri siswa (internal) yaitu faktor biologis (jasmani), faktor psikologis, dan kemampuan kognitif. Kedua faktor eksternal yang meliputi faktor lingkungan keluarga, faktor lingkungan sekolah. Dalam hal ini merupakan suatu kenyataan yang menjadi tantangan para guru sekolah dasar untuk dapat menciptakan suasana belajar yang kondusif, yang sesuai dengan materi yang akan dibelajarkan. Kemudian dikemas sedemikian rupa, agar siswa selalu ikut terlibat aktif baik fisik maupun psikologis dari awal sampai akhir pembelajaran.

Berdasarkan observasi awal yang telah dilakukan di kelas V pada Gugus I Kecamatan Jembrana, ditemukan beberapa permasalah yaitu: (1) guru sulit melakukan sesi diskusi kelompok pada siswa, (2) model pembelajaran yang monoton, dan (3) hasil belajar bahasa Indonesia yang rendah. Temuan ini di perkuat oleh hasil observasi kepada guru kelas $\mathrm{V}$ yang menyatakan bahwa sulitnya mengkondisikan kelas pada pembelajaran bahasa Indonesia karena bagi siswa pembelajaran bahasa Indonesia adalah pembelajaran yang membosankan.

UAS Bahasa Indonesia peserta didik kelas V di Gugus I Kecamatan Jembrana masih di bawah KKM. Dari 8 sekolah yang terdapat di dalamnya dengan jumlah peserta didik 162, yang mencapai KKM sebanyak 67 orang dan tidak mencapai KKM sebanyak 95 orang. Jadi dapat disimpulkan bahwa peserta didik yang mencapai KKM lebih sedikit dibandingkan dengan yang tidak mencapai KKM. Hal ini diakibatkan karena pembelajaran yang monoton sehingga hal tersebut dapat menyebabkan hasil belajar bahasa Indonesia yang rendah.

Berdasarkan permasalahan yang ditemukan pada kelas V di Gugus I Jembrana dapat diberikan solusi dengan menggunakan Pendekatan Saintifik. Pendekatan Saintifik atau pendekatan ilmiah berarti konsep dasar yang menginspirasi atau melatar belakangi perumusan metode mengajar dengan menerapkan karakteristik yang ilmiah. Pendekatan pembelajaran ilmiah (scientific teaching) merupakan bagian dari pendekatan pedagogis pada pelaksanaan pembelajaran dalam kelas yang melandasi penerapan metode ilmiah. Pengertian penerapan pendekatan ilmiah dalam pembelajaran tidak hanya fokus pada bagaimana mengembangkan kompetensi peserta didik dalam melakukan observasi atau eksperimen, namun bagaimana mengembangkan pengetahuan dan keterampilan berpikir sehingga dapat mendukung aktivitas kreatif dalam berinovasi atau berkarya.

Disamping pendekatan saintifik, pembelajaran juga perlu berorientasi pada suatu teknik pembelajaran yang membangkitkan semangat belajar siswa. Adapun teknik pembelajaran yang menarik untuk siswa adalah Cooperative Integrated Reading and Composition (CIRC). Menurut (Ngalimun dkk, 2016:240) Cooperative, Integrated, Reading, and Composition(CIRC) adalah komposisi terpadu membaca dan menulis secara koperatif kelompok. Dalam Cooperative Integrated Reading and Composition (CIRC) siswa dituntut untuk menguasai pikiran utama dari suatu wacana dan kemampuan membaca dan menulis lainnya secara bersama-sama. Siswa dibagi kelompok oleh guru, kemudian menyelesaikan masalah yang terdapat dari bacaan tersebut secara bersama-sama .

CIRC dalam pembelajaran bahasa Indonesia adalah gambar berseri. Gambar berseri merupakan rangkaian gambar yang mempunyai keterkaitan kejadian antara gambar satu dengan gambar yang lainnya. Gambar-gambar tersebut menggambarkan sebuah rangkaian kejadian atau suatu peristiwa dari awal kejadian sampai akhir kejadian. Gambar ini digunakan untuk merangsang, daya pikir siswa dalam membaca dan mencari suatu ide pokok dalam sebuah wacana serta dapat memecahkan suatu masalah di dalamnya.

Adapun tujuan penelitian ini adalah untuk mengetahui pengaruh pembelajaran berpendekatan saintifik berorientasi Cooperative, Integrated, Reading, And Composition (CIRC) terhadap hasil belajar bahasa Indonesia. Untuk mengetahui pengaruh pembelajaran berpendekatan saintifik berorientasi Cooperative, Integrated, Reading, And Composition (CIRC) terhadap hasil belajar bahasa Indonesia dengan kemampuan verbal dikendalikan. Untuk mengetahui besarnya kontribusi kemampuan verbal terhadap hasil belajar bahasa Indonesia pada siswa kelas $\mathrm{V}$ di gugus I Kecamatan Jembrana.

\section{Metode}

Jenis penelitian ini adalah penelitian pre-ekperimen dengan desain penelitian post-test only control group. Populasi dalam penelitian ini adalah siswa kelas V SD Gugus I Kecamatan Jembrana Tahun 2018/2019 yang terdiri dari 8 kelas seperti pada tabel 01 berikut. 
Tabel 01 Sebaran Data Populasi

\begin{tabular}{clll}
\hline No & Nama Sekolah & Kelas & Jumlah siswa \\
\hline 1 & SDN 1 Yehkuning & V & 24 Siswa \\
2 & SDN 2 Yehkuning & V & 17 Siswa \\
3 & SDN 1 Airkuning & V & 16 Siswa \\
4 & SDN 2 Airkuning & V & 12 Siswa \\
5 & SDN 1 Perancak & V & 24 Siswa \\
6 & SDN 2 Perancak & V & 34 Siswa \\
7 & SDN 1 Sangkaragung & V & 24 Siswa \\
8 & SDN 2 Sangkaragung & V & 11 Siswa \\
\hline & Total Jumlah Siswa & & 162 Siswa \\
\hline
\end{tabular}

Sebelum menentukan sampel, perlu dilakukan uji kesetaraan. Uji kesetaraan dilakukan untuk menentukan sekolah mana saja yang layak digunakan sebagai sampel dalam penelitian ini. Uji kesetaraan penelitian ini menggunakan rumus ANAVA A dengan tarif signifikan $5 \%$. Kriteria pengujian dengan menggunakan analisis varians satu jalur (Anava $A$ ), jika $f_{\text {hitung }} \geq f_{\text {tabel }}$ maka $\mathrm{H}_{0}$ ditolak dan $\mathrm{H}_{1}$ diterima sehingga kelompok tidak setara. Jika $\mathrm{f}_{\text {hitung }} \leq \mathrm{f}_{\text {tabel }}$ maka $\mathrm{H}_{0}$ diterima dan $\mathrm{H}_{1}$ ditolak sehingga kelompok setara. Dengan db pembilang (a-1) dan db penyebut $(\mathrm{N}-\mathrm{a})$ dan taraf signifikan $5 \%$.

Sampel dalam penelitian ini diambil dari populasi terjangkau dengan teknik Random Sampling dan dari hasil pengacakan diperoleh siswa kelas V di SD Negeri 2 Yehkuning dengan jumlah 17 siswa SD Negeri 1 Yehkuning dengan jumlah 24 siswa.

Pengumpulan data dalam penelitian ini meliputi data Hasil belajar bahasa Indonesia dan kemampuan verbal siswa kelas $\mathrm{V}$ di gugus I kecamatan Jembrana. Dalam penelitian ini data hasil belajar bahasa Indonesia di ukur menggunakan tes pilihan ganda sedangkan kemampuan verbal di ukur menggunakan tes kemampuan verbal pilihan ganda. Sebelum instrument digunakan, terlebih dahulu dilakukan uji pakar untuk melihat kualitas isi dari instrument, kemudian instrument di ujikan ke beberapa orang siswa untuk mementukan validitas tiap butir soal yang akan diuji dengan menggunakan korelasi Point Biserial, uji reliabilitas menggunakan KR-21, uji tingkat kesukaran, dan diuji daya bedanya. Berdasarkan hasil uji coba intrumen, diperoleh dari 30 soal yang diujikan dan akan digunakan sebagai instrument posttest.

Data yang diperoleh dari penelitian ini adalah data kuantitatif berupa skor hasil belajar Bahasa Indonesi siswa kelas $\mathrm{V}$ dengan kovariabel kemampuan verbal. Data yang diperoleh diuji secara deskritif yang terdiri dari perhitungan mean, median modus, standar deviasi, varians, maksimum, minimum, dan jangkauan, serta secara inferensial untuk pengujain hipotesis yang diajukan. Sebelum melakukan pengujian hipotesis, terlebih dahulu dilakukan uji prasyarat yaitu uji normalitas dan uji homogenitas. Pengujian normalitas sebaran data dilakukan dengan Uji Chi-Square. Nilai $\chi^{2}$ hitung dibandingkan dengan nilai $\chi^{2}$ tabel pada taraf signifikan $5 \%$. Jika nilai $\chi^{2}$ hitung lebih kecil dari nilai $\chi^{2} t_{\text {abel }}$ maka hipotesis nol yang menyatakan bahwa data berasal dari populasi yang berdistribusi normal dapat diterima. Pengujian homogenitas data dilakukan dengan Uji $F$. Nilai $F_{\text {hitung }}$ dibandingkan dengan $F_{\text {tabel }}$ pada taraf signifikan $5 \%$. Jika $F_{\text {hitung }}<F_{\text {tabel }}$ maka $H_{0}$ diterima sehingga dapat disimpulkan bahwa varians data homogen. Pengujian hipotesis dilakukan denggan menggunakan uji ANAVA satu jalur dan uji ANAKOVA.

\section{Hasil dan Pembahasan}

Data yang diperoleh dari hasi penelitian ini adalah data hasil belajar bahasa Indonesia dan kemampuan verbal siswa pada kelas eksperimen dan kontrol yang diperoleh dari hasil pemberian posttest. Pada tabel 2 berikut akan disajikan rangkuman hasil analisis deksritif, skor hasil belajar siswa pada kelompok eksperimen dna kontrol. 
Tabel 02 Analisis Deskritif Data Hasil Penelitian

\begin{tabular}{llllll}
\hline \multirow{2}{*}{ No } & \multirow{2}{*}{ Hasil Analisis } & \multicolumn{2}{l}{$\begin{array}{l}\text { Hasil Belajar Bahasa } \\
\text { Indonesia }\end{array}$} & \multicolumn{2}{l}{ Kemampuan Verbal } \\
\cline { 3 - 6 } & & Eksperimen & Kontrol & Eksperimen & Kontrol \\
\hline 1 & N & 17 & 24 & 17 & 24 \\
2 & Mean & 21,25 & 18,29 & 21,06 & 17,58 \\
3 & Median & 20,59 & 18,36 & 20,90 & 17,64 \\
4 & Modus & 21,50 & 18,70 & 20,83 & 17,70 \\
5 & Standar Deviasi & 2,40 & 2,97 & 2,16 & 2,73 \\
6 & Varian & 5,74 & 8,82 & 4,68 & 7,47 \\
7 & Skor Maksimal & 25 & 23 & 24 & 22 \\
8 & Skor Minimal & 17 & 12 & 16 & 13 \\
\hline
\end{tabular}

Berdasarkan data tersebut, hasil belajar Bahasa Indonesia pada kelompok eksperimen melalui pembelajaran berpendekatan saintifik berorientasi Cooperative, Integrated, Reading, And Composition (CIRC), lebih tinggi dari kelompok kontrol dengan model pembelajaran konvensional. Berdasarkan data tersebut, kemampuan verbal Bahasa Indonesia pada kelompok eksperimen melalui pembelajaran berpendekatan saintifik berorientasi Cooperative, Integrated, Reading, And Composition (CIRC), lebih tinggi dari kelompok kontrol dengan model pembelajaran konvensional.

Sebelum melakukan pengujian hipotesis data yang diperoleh terlebih dahulu dilakukan uji normalitasnya. Hasil pengujian normalitas data hasil belajar bahasa Indonesia dan kemampuan verbal siswa kelas eksperimen eksperimen dapat dilihat pada tabel 3 berikut.

Tabel 3 Uji Normalitas Data Hasil Penelitian

\begin{tabular}{llllll}
\hline \multirow{2}{*}{ No } & \multirow{2}{*}{ Normalitas Data } & \multicolumn{2}{l}{$\begin{array}{l}\text { Hasil Belajar Bahasa } \\
\text { Indonesia }\end{array}$} & \multicolumn{2}{l}{ Kemampuan Verbal } \\
\cline { 3 - 6 } & & Eksperimen & Kontrol & Eksperimen & Kontrol \\
\hline 1 & Statistik & 0,157 & 0,136 & 0,158 & 0,103 \\
2 & Df & 17 & 24 & 17 & 24 \\
3 & Sig & 0,200 & 0,2000 & 0,200 & 0,200 \\
\hline
\end{tabular}

Berdasarkan hasil uji normalitas hasil belajar di atas, dapat dilihat bahwa signifikansi hasil belajar kelompok eksperimen dan kelompok kontrol 0,200 $>0,05$. Hal ini menunjukkan bahwa sebaran data hasil belajar bahasa Indonesia berdistribusi normal. Berdasarkan hasil uji normalitas kemampuan verbal di atas, dapat dilihat bahwa signifikansi kemampuan verbal kelompok eksperimen dan kelompok kontrol 0,200 >0,05. Hal ini menunjukkan bahwa sebaran data kemampuan verbal bahasa Indonesia berdistribusi normal.

Uji homogenitas varians antar kelompok bertujuan untuk memeriksa kesamaan varians antar kelompok perlakuan. Dalam penelitian ini, uji homogenitas dilakukan terhadap varians pasangan antar kelompok eksperimen dan kontrol. Rekapitulasi hasil uji homogenitas varians antar kelompok eksperimen dan kontrol disajikan pada 4 berikut.

Tabel 04 Rangkuman Hasil Uji Homogenitas Varians

\begin{tabular}{llll}
\hline Data & Based on Mean & Signifikansi & Kesimpulan \\
\hline Hasil Belajar Bahasa Inodnesia & 0,347 & 0,05 & Homogen \\
Kemampuan Verbal & 0,320 & 0,05 & Homogen \\
\hline
\end{tabular}


Selanjutnya dilakukan uji linieritas, hasil pengujian linieritas seperti pada tabel 05 berikut.

Tabel 05 Hasil Pengujian Linieritas

\begin{tabular}{|c|c|c|c|c|c|c|c|}
\hline & & & $\begin{array}{l}\text { Sum of } \\
\text { Squares }\end{array}$ & Df & $\begin{array}{l}\text { Mean } \\
\text { Squares }\end{array}$ & $\mathbf{F}$ & Sig. \\
\hline \multirow{6}{*}{$\begin{array}{l}\text { HASIL } \\
\text { BELAJAR } \\
\text { KEMAMPUAN } \\
\text { VERBAL }\end{array}$} & & \multirow{5}{*}{$\begin{array}{l}\text { (Combined } \\
\text { Linearity } \\
\text { Deviation } \\
\text { from } \\
\text { Linearity }\end{array}$} & 171,861 & 11 & 15,624 & 2,078 & 0,057 \\
\hline & Between & & 92,673 & 1 & 92,673 & 12,323 & 0,001 \\
\hline & Groups & & 79,188 & 10 & 7,919 & 1,053 & 0,427 \\
\hline & & & & & & & \\
\hline & Groups & & 218,090 & 29 & 7,520 & & \\
\hline & Total & & 389,951 & 40 & & & \\
\hline
\end{tabular}

Berdasarkan hasil uji linearitas dengan bantuan SPSS 25, diperoleh nilai sig. Deviation from Linearity sebesar 0,427 >0,05. Maka dapat disimpulkan bahwa ada hubungan linear secara signifikan antara variabel Hasil Belajar (X) dengan Kemampuan Verbal $(Y)$.

Dari hasil uji prasyarat yaitu uji normalitas, uji homogenitas, dan uji linearitas, diperoleh bahwa data hasil belajar dan kemampuan verbal dari kelompok eksperimen dan kelompok kontrol berdistribusi normal, homogen, dan linear. Berdasarkan hal tersebut, dilanjutkan pada pengujian hipotesis penelitian atau hipotesis alternatif $\left(\mathrm{H}_{1}\right)$ yang telah dibahas pada kajian teori. Dalam penelitian ini diuji dari 3 hipotesis yaitu sebagai berikut.

$\mathrm{H}_{1}$ : Terdapat pengaruh yang signifikan pembelajaran berpendekatan saintifik berorientasi Cooperative, Integrated, Reading, And Composition (CIRC) terhadap hasil belajar bahasa Indonesia.

$\mathrm{H}_{0}$ : Tidak terdapat pengaruh yang signifikan pembelajaran berpendekatan saintifik berorientasi Cooperative, Integrated, Reading, And Composition (CIRC) terhadap hasil belajar bahasa Indonesia.

Pengujian hipotesis tersebut dilakukan dengan uji ANAVA A dengan bantuan SPSS. Rangkuman hasil Uji ANAVA A dapat dilihat pada tabel berikut.

Tabel 06 Hasil Uji Anava

\begin{tabular}{llllll}
\hline & JK & Df & RJK & F & Sig \\
\hline $\begin{array}{l}\text { Antar } \\
\text { Kelompok (A) }\end{array}$ & 96,875 & 1 & 96,875 & 12,891 & 0,001 \\
$\begin{array}{l}\text { Dalam } \\
\text { Kelompok (dal) }\end{array}$ & 293,076 & 39 & 7,515 & & \\
\hline Total & $\mathbf{3 8 9 , 9 5 1}$ & $\mathbf{4 0}$ & & & \\
\hline
\end{tabular}

Berdasarkan ringasan hasil Uji ANAVA A dengan bantuan SPSS 25, diperoleh hasil nilai signifikansi $0,001<0,05$. Dengan demikian $\mathrm{H}_{0}$ ditolak dan $\mathrm{H}_{1}$ diterima, yang artinya Terdapat pengaruh yang signifikan pembelajaran berpendekatan saintifik berorientasi Cooperative, Integrated, Reading, And Composition (CIRC) terhadap hasil belajar bahasa Indonesia.

Kemudian untuk pengujian hipotesis kedua diuji dengan menggunakan uji ANAKOVA, hipotesis 2 yang berbunyi:

$\mathrm{H}_{1}$ : Terdapat pengaruh yang signifikan pembelajaran berpendekatan saintifik berorientasi Cooperative, Integrated, Reading, And Composition (CIRC) dengan pengendalian kemampuan verbal terhadap hasil belajar bahasa Indonesia.

$\mathrm{H}_{0}$ : Tidak terdapat pengaruh yang signifikan pembelajaran berpendekatan saintifik berorientasi Cooperative, Integrated, Reading, And Composition (CIRC) dengan pengendalian kemampuan verbal terhadap hasil belajar bahasa Indonesia. 
Tabel 07 Hasil Analisis Kovarian

\begin{tabular}{|c|c|c|c|c|c|}
\hline $\begin{array}{l}\text { Sumber } \\
\text { Variasi }\end{array}$ & JK & $\mathrm{db}$ & RJK & $\mathbf{F}$ & Sig. \\
\hline Correct & 126,502 & 2 & 63,251 & 9,123 & 0,001 \\
\hline Intercept & 112,566 & 1 & 112,566 & 16,237 & 0,000 \\
\hline $\begin{array}{l}\text { Kemampuan } \\
\text { Verbal }\end{array}$ & 29,627 & 1 & 29,627 & 4,273 & 0,046 \\
\hline $\begin{array}{l}\text { Variabel } \\
\text { Error } \\
\text { Total }\end{array}$ & $\begin{array}{l}24,563 \\
263,449 \\
16117,0\end{array}$ & $\begin{array}{l}1 \\
38 \\
41\end{array}$ & $\begin{array}{l}24,563 \\
6,933\end{array}$ & 3,543 & 0,067 \\
\hline $\begin{array}{l}\text { Corrected } \\
\text { Total }\end{array}$ & 389,951 & 40 & & & \\
\hline
\end{tabular}

Berdasarkan hasil Analisis Kovarians Satu Jalur (ANAKOVA A) dengan bantuan SPSS, diperoleh hasil signifikansi kemampuan verbal 0,046 $<0,05$. Dengan demikian dapat disimpulkan bahwa $\mathrm{H}_{0}$ ditolak dan $\mathrm{H}_{1}$ diterima, yang artinya terdapat pengaruh yang signifikan pembelajaran berpendekatan saintifik berorientasi Cooperative, Integrated, Reading, And Composition $(C I R C)$ dengan pengendalian kemampuan verbal terhadap hasil belajar bahasa Indonesia pada siswa kelas V di gugus I Kecamatan Jembrana tahun pelajaran 2018/2019.

Untuk menguji hipotesis III, yaitu mengetahui hubungan kovariabel kemampuan verbal terhadap hasil belajar bahasa Indonesia siswa digunakan korelasi product moment dengan bantuan SPSS. Adapun hipotesis III adalah sebagai berikut.

$\mathrm{H}_{1}$ : Terdapat kontribusi kemampuan verbal terhadap hasil belajar bahasa Indonesia siswa kelas V di gugus I Kecamatan Jembrana tahun pelajaran 2018/2019.

$\mathrm{H}_{0}$ : Tidak terdapat kontribusi kemampuan verbal terhadap hasil belajar bahasa Indonesia siswa kelas V di gugus I Kecamatan Jembrana tahun pelajaran 2018/2019.

Tabel 08 Hasil Uji Korelasi Product Moment

\begin{tabular}{lll}
\hline Uji & Person Correlation & Sig (2-tailed) \\
\hline $\begin{array}{l}\text { Korelasi Product Moment } \\
\text { Karl Pearson }\end{array}$ & $0,487^{\star *}$ & 0,001 \\
\hline
\end{tabular}

Berdasarkan uji korelasi product moment karl pearson dengan bantuan SPSS, diperoleh hasil nilai pada correlation table yaitu 0.487 dengan bintang dua, menandakan koefisien korelasi signifikan. Nilai signifikansi yaitu sebesar $0,001<0,05$. Oleh karena itu $\mathrm{H}_{0}$ ditolak dan $\mathrm{H}_{1}$ diterima, sehingga terdapat kontribusi kemampuan verbal terhadap hasil belajar Bahasa Indonesia siswa kelas V di gugus I kecamatan Jembrana tahun pelajaran 2018/2019. Kontribusi kemampuan verbal terhadap hasil belajar Bahasa Indonesia siswa bernilai 0,487 atau 48,7\%.

Berdasarkan hasil uji hipotesis I, diperoleh hasil yaitu terdapat pengaruh yang signifikan pembelajaran berpendekatan saintifik berorientasi Cooperative, Integrated, Reading, And Composition (CIRC) terhadap hasil belajar bahasa Indonesia pada siswa kelas $\mathrm{V}$ di gugus 1 kecamatan Jembrana tahun pelajaran 2018/2019. Siswa yang mengikuti pembelajaran berpendekatan saintifik berorientasi Cooperative, Integrated, Reading, And Composition (CIRC) memperoleh skor hasil belajar Bahasa Indonesia yang lebih tinggi dibandingkan model pembelajaran konvensional.

Dengan hasil uji hipotesis yang telah diungkapkan tersebut, maka pembelajaran berpendekatan saintifik berorientasi Cooperative, Integrated, Reading, And Composition (CIRC) tepat diterapkan dalam pembelajaran Bahasa Indonesia pada siswa kelas $\mathrm{V}$ di gugus 1 kecamatan Jembrana. Tingginya hasil belajar yang diperoleh siswa terutama pada kelompok eksperimen, dikarenakan pendekatan saintifik dalam pembelajaran tidak hanya fokus pada bagaimana mengembangkan kompetensi peserta didik dalam melakukan observasi atau 
eksperimen, namun bagaimana mengembangkan pengetahuan dan keterampilan berpikir sehingga dapat mendukung aktivitas kreatif dalam berinovasi atau berkarya.

Pendekatan saintifik dalam pembelajaran melibatkan keterampilan proses seperti mengamati, mengklasifikasi, mengukur, meramalkan, dan menyimpulkan. Dalam melaksanakan proses-proses tersebut, bantuan guru diperlukan. Akan tetapi bantuan guru tersebut harus semakin berkurang dengan semakin bertambah dewasanya siswa atau semakin tingginya kelas siswa. Siswa lebih banyak mencari tahu dan bukan diberi tahu (Kemendikbud, dalam Widiani et al, 2016). Maksudnya adalah informasi bisa berasal dari mana saja, kapan saja, tidak tergantung pada informasi searah dari guru. Oleh karena itu kondisi pembelajaran yang tercipta, diarahkan untuk mendorong siswa dalam mencari tahu dari berbagai sumber melalui observasi dan bukan diberi tahu. Dalam penerapan pendekatan saintifik, peran guru adalah sebagai fasilitator. Pembelajaran seyogyanya sebanyak mungkin melibatkan siswa agar mereka mampu bereksplorasi untuk membentuk kompetensi dengan menggali berbagai potensi, dan kebenaran secara ilmiah (Mulyasa, 2013:42). Tugas guru tidak hanya menyampaikan informasi kepada siswa tetapi harus kreatif memberikan layanan dan kemudahan belajar kepada seluruh siswa agar mereka dapat belajar dalam suasana yang menyenangkan, gembira, penuh semangat, tidak cemas, dan berani mengemukakan pendapat secara terbuka.

Pembelajaran berpendekatan saintifik yang diorientasikan dengan suatu tipe pembelajaran kooperatif membuat pembelajaran menjadi lebih efektif. Ngalimun dkk (2016:240) bahwa, CIRC (Cooperative, Integrated, Reading, And Composition) adalah komposisi terpadu membaca dan menulis secara koperatif kelompok. Dengan adanya perpaduan membaca dan menulis maka siswa akan dapat belajar lebih baik karena memadukan kemampuan audio dan visual siswa. Hal ini juga sesuai dengan kelebihan CIRC(Cooperative, Integrated, Reading, And Composition) yaitu dengan penerapan CIRC (Cooperative, Integrated, Reading, And Composition) pengalaman dan kegiatan belajar siswa akan selalu relevan dengan tingkat perkembangan anak. Seluruh kegiatan belajar lebih bermakna bagi siswa sehingga hasil belajar siswa dapat bertambah lebih lama. Pembelajaran terpadu dapat menumbuh kembangkan keterampilan berpikir siswa. Pembelajaran terpadu menyajikan kegiatan yang bersifat pragmatis (bermanfaat) sesuai dengan permasalahan yang sering ditemui dalam lingkungan siswa. Pembelajaran terpadu dapat menumbuhkan motivasi belajar siswa ke arah belajar yang dinamis, optimal, dan tepat guna. Pembelajaran terpadu dapat menumbuhkembangkan interaksi sosial siswa, kerja sama, toleransi, respek terhadap gagasan orang lain. Membangkitkan motivasi belajar serta memperluas wawasan dan aspirasi guru dalam mengajar. Kelebihan tersebut yang dapat meningkatkan hasil belajar Bahasa Indonesia siswa.

Pada penerapan pembelajaran berpendekatan saintifik berorientasi CIRC (Cooperative, Integrated, Reading, And Composition ) yang diterapkan dalam penelitian ini sesuai dengan sintaks pembelajaran berpendekatan saintifik berorientasi CIRC (Cooperative, Integrated, Reading, And Composition) yang telah dikemukakan pada BAB II. Fase awal pembelajarannya yaitu orientasi, guru melakukan apersepsi dan pengetahuan awal peserta didik tentang materi yang akan diberikan. Fase kedua yaitu organisasi, guru membagi peserta didik ke dalam beberapa kelompok, dengan memperhatikan keheterogenan akademik. Membagikan bahan bacaan tentang materi yang akan dibahas kepada peserta didik. Selain itu menjelaskan mekanisme diskusi kelompok dan tugas yang harus diselesaikan selama proses pembelajaran berlangsung. Fase ketiga yaitu pengenalan konsep. Siswa mengenal tentang suatu konsep baru yang mengacu pada hasil penemuan selama eksplorasi. Pengenalan ini bisa didapat dari kegiatan pengamatan keterangan guru, buku paket, film, kliping, poster atau media lainnya (mengamati). Pada tahap pengenalan kegiatan saintifik setelah mengamati adalah menanya. Siswa menanyakan hal yang berlum dimengerti kepada guru untuk memperoleh pengetahuan yang utuh (menanya). Setelah menanyakan hal yang belum dimengerti peserta didik diminta mengumpulkan informasi yang diperolehnya dari kegiatan mengamti dan menanyakan hal yang belum dimengerti kepada guru (mengumpulkan informasi). Setelah semua informasi terkumpul, siswa secara berkelompok menganalisis informasi tersebut untuk dapat menjawab tugas yang telah diberikan oleh guru (menganalisis informasi atau mengasosiasi). Fase keempat, yaitu fase 
publikasi. Peserta didik mengkomunikasikan hasil temuan-temuannya, membuktikan, memperagakan tentang materi yang dibahas baik dalam kelompok maupun di depan kelas (mengomunikasikan). Fase kelima, yaitu fase penguatan dan refleksi. Dalam fase ini guru memberikan penguatan berhubungan dengan materi yang dipelajari melalui penjelasanpenjelasan ataupun memberikan contoh nyata dalam kehidupan seharihari. Selanjutnya peserta didik pun diberi kesempatan untuk merefleksikan dan mengevaluasi hasil pembelajarannya.

Seluruh siswa sangat antusias belajar dengan menggunakan pembelajaran berpendekatan saintifik berorientasi CIRC (Cooperative, Integrated, Reading, And Composition) Keberhasilan penerapan pembelajaran berpendekatan saintifik berorientasi CIRC (Cooperative, Integrated, Reading, And Composition) didukung oleh hasil penelitian Sugiartini (2013) yang berjudul "Pengaruh Model Pembelajaran Cooperative Integrated Reading and Composition (CIRC) Terhadap Hasil Belajar IPS Kelas IV Gugus I Kecamatan Manggis". Hasil penelitiannya menunjukkan bahwa, terdapat perbedaan yang signifikan hasil belajar IPS antara siswa yang dibelajarkan dengan model pembelajaran CIRC dan siswa yang dibelajarkan dengan model pembelajaran konvensional. Rata-rata hasil belajar menggunakan model CIRC lebih besar dibanding model konvensional, sehingga dapat disimpulkan bahwa pembelajaran dengan model pembelajaran CIRC berpengaruh terhadap hasil belajar. Sejalan dengan penelitian tersebut, Sumayasa et al (2015) melakukan penelitian yang berjudul "Pengaruh Implementasi Pendekatan Saintifik terhadap Motivasi Belajar dan Hasil Belajar Bahasa Indonesia pada Siswa Kelas VI di Sekolah Dasar Se Gugus VI Kecamatan Abang, Karangasem". Hasil penelitiannya menunjukkan bahwa Pertama, Terdapat pengaruh motivasi belajar bahasa Indonesia antara siswa yang mengikuti pelajaran dengan pendekatan saintifik dan siswa yang belajar dengan model pembelajaran konvensional pada siswa kelas VI Gugus VI Kecamatan Abang, Karangasem, motivasi belajar siswa yang mengikuti model pembelajaran saintifik (kelompok eksperimen) hasilnya lebih baik daripada motivasi belajar siswa yang mengikuti model pembelajaran konvensional (kelompok kontrol). Kedua, hasil belajar siswa yang mengikuti model pembelajaran saintifik (kelompok eksperimen) hasilnya lebih baik daripada hasil belajar siswa yang mengikuti model pembelajaran konvensional (kelompok kontrol). Ketiga, motivasi dan hasil belajar siswa yang mengikuti model pembelajaran saintifik (kelompok eksperimen) hasilnya lebih baik daripada motivasi dan hasil belajar siswa yang mengikuti model pembelajaran konvensional (kelompok kontrol).

Berbeda halnya dengan pembelajaran dengan model pembelajaran konvensional. Dalam penelitian ini, guru berperan sebagai pemberi informasi kepada siswa, sedangkan siswa berperan memperoleh informasi dengan tepat melalui kegiatan mendengarkan dan membaca informasi. Penjelasan yang diberikan oleh guru masih berorientasi pada buku dan tidak menggunakan model pembelajaran. Hal ini menyebabkan siswa kurang bersemangat dalam belajar dan kurang dapat memahami materi pembelajarn. Pada pembelajaran konvensional, penekannanya sering hanya pada penyelesaian tugas, sehingga hasil belajar siswa rendah. Hal ini akan menyebabkan hasil belajar bahasa Indonesia siswa menjadi kurang optimal.

Berdasarkan pembahasan tersebut, maka pembelajaran berpendekatan saintifik berorientasi CIRC (Cooperative, Integrated, Reading, And Composition) lebih tepat diterapkan untuk meningkatkan hasil belajar bahasa Indonesia siswa sekolah dasar, dibandingkan model pembelajaran konvensional.

Berdasarkan hasil hipotesis II, hasil belajar bahasa Indonesia akan lebih baik apabila didukung oleh kemampuan verbal siswa yang baik. Hal ini didukung oleh pernyataan yang dikemukakan oleh Budiarta (2010) bahwa kemampuan verbal adalah kemampuan melihat hubungan antar ide yang berbeda satu sama lain dan kemampuan untuk mengkombinasikan ide-ide tersebut ke dalam asosiasi baru. Anak-anak yang mempunyai kemampuan tersebut mampu membuat pola-pola baru berdasarkan prakarsanya sendiri menurut ide-ide yang terbentuk dalam kognitif mereka. Kemampuan verbal diartikan sebagai kemampuan untuk makna atau arti kata tersebut kemudian memahami fungsi dan penggunaan kata-kata tersebut serta memahami hubungan suatu kata dengan kata-kata yang lain. Jadi, untuk memudahkan dalam menghadapi tes kemampuan verbal, yang dibutuhkan dan yang menentukan adalah 
perbendaharaan kata yang banyak. Kemampuan untuk mengenali suatu kata, mengetahui dan memahami makna atau arti kata tersebut kemudian memahami hubungan suatu kata dengan kata-kata yang lain. Oleh karena itu kemampuan verbal ini berkaitan dengan bahasa, maka siswa yang berkemampuan verbal akan memiliki potensi yang besar untuk mencapai hasil yang baik dalam pelajaran bahasa, termasuk bahasa Indonesia.

Kemampuan verbal siswa yang dibelajarkan dengan pembelajaran berpendekatan saintifik berorientasi, Integrated, Reading, And Composition (CIRC) lebih baik daripada siswa yang dibelajarkan dengan model pembelajaran konvensional. Hal ini dikarenakan pada langkah pembelajaran berpendekatan saintifik berorientasi Cooperative, Integrated, Reading, And Composition (CIRC) siswa dilatih untuk bekerja sama, kemudian mengaitkan antara kemampuan membaca dan menulis siswa. Apabila kemampuan membaca dan menulis siswa dapat dilatih secara bersamaan, maka kemampuan verbal siswa akan meningkat. Selain itu, pembelajaran ilmiah yang meliputi kegaitan mengamati, menanya, mengumpulkan informasi, menganalisis informasi, dan mengomunikasikan, membuat siswa dapat meningkatkan kemampuan membaca dan menulis secara lebih baik. Hal ini juga akhirnya berpengaruh pada kemampuan verbal siswa.

Adanya pengaruh kemampuan verbal terhadap hasil belajar siswa juga didukung oleh hasil penelitian Pradnyani (2014) yang berjudul "Pengaruh Penerapan Asesmen Kinerja terhadap kemampuan menulis dalam bahasa Jepang dengan Kovariabel kemampuan verbal pada siswa kelas XII IPB SMA Negeri 1 Banjarangkan". Pada penelitian ini menyebutkan bahwa Hasil penelitian menunjukan bahwa, 1) terdapat perbedaan kemampuan menulis dalam bahasa Jepang yang signifikan antara siswa yang mengikuti pembelajaran menulis dengan pendekatan proses berbasis asesmen kinerja dengan siswa yang mengikuti pembelajaran dengan asesmen konvensional ( $F=501,843$ dengan $\alpha<0,05) ; 2)$ setelah kemampuan verbal dikendalikan, terdapat perbedaan kemampuan menulis dalam bahasa Jepang yang signifikan antara siswa yang mengikuti pembelajaran menulis dengan pendekatan proses berbasis asesmen kinerja dengan siswa yang mengikuti pembelajaran dengan asesmen konvensional ( $F=125,259$ dengan $\alpha<0,05)$; 3 ) adanya kontribusi kemampuan verbal terhadap kemampuan menulis siswa dengan koefisien determinan sebesar $82,5 \%$.

Jadi agar mencapai hasil belajar bahasa Indonesia yang baik, siswa perlu dilatih kemampuan verbalnya dengan penerapan model pembelajaran Cooperative, Integrated, Reading, And Composition (CIRC).

Hasil uji hipotesis III menunjukkan bahwa, terdapat kontribusi kemampuan verbal terhadap hasil belajar Bahasa Indonesia siswa. Hal ini menunjukkan bahwa kemampuan verbal siswa yang baik akan memberikan hasil belajar Bahasa Indonesia yang baik. Siregar dkk (2014) menyatakan bahwa, kemampuan verbal yang baik diduga memiliki kecakapan yang mensyaratkan keakraban dengan bahasa tertulis maupun lisan untuk menyimak, menelaah isi dari suatu pernyataan, berani mengungkapkan ide, gagasan, pendapat, dan pikirannya, sehingga siswa tersebut dapat mengambil suatu kesimpulan yang tepat. Semua hal itu dipelajari dalam pembelajaran Bahasa Indonesia, yang artinya dengan adanya kemampuan verbal baik, maka baik pula dalam mengikuti pembelajaran Bahasa Indonesia. Kemampuan verbal merupakan kemampuan bawaan yang sudah ada dari lahir sehingga tidak dapat ditingkatkan menjadi lebih tinggi karena ia merupakan kecerdasan bawaan akan tetapi kemampuan verbal dapat dioptimalkan dengan cara banyak latihan berupa menyerap kosakata baru dan banyak latihan untuk berhitung.

Satria dan Riqo WS (dalam Pradyani, 2014) menekankan bahwa salah satu yang mempengaruhi kemampuan bahasa adalah kemampuan verbal. Kemampuan verbal dalam hal ini hanya menyangkut dimensi intelektual yang merupakan kemampuan potensial yang dimiliki oleh siswa dalam melakukan konsep-konsep yang diungkapkan dalam bentuk kata-kata dan kemampuan untuk berpikir dengan menggunakan bahasa. Kemampuan verbal erat kaitannya dengan kecerdasan linguistik-verbal dimana siswa yang memiliki kebahasaan/linguistik yang tinggi akan lebih mudah mempelajari bahasa. Kemampuan untuk mengenali suatu kata, mengetahui dan memahami makna atau arti kata tersebut kemudian memahami hubungan 
suatu kata dengan kata-kata yang lain. Oleh karena itu kemampuan verbal ini berkaitan dengan bahasa, maka siswa yang berkemampuan verbal akan memiliki potensi yang besar untuk mencapai Hasil yang baik dalam pelajaran bahasa, termasuk bahasa Indonesia.

Adapun ciri-ciri anak yang memiliki kemampuan verbal menurut Sudjana (2005), yaitu suka menulis kreatif, suka mengarang kisah khayalan atau menceritakan lelucon, sangat hafal nama, tempat, tanggal, atau hal-hal kecil, membaca di waktu senggang, mengeja kata dengan tepat dan mudah, suka mengisi teka-teki silang, menikmati dengan cara mendengarkan, unggul dalam mata pelajaran bahasa. Apabila siswa memiliki ciri-ciri tersebut, maka ia akan dengan mudah mengikuti pembelajaran Bahasa Indonesia, sehingga hasil belajar Bahasa Indonesia siswa tinggi.

Berdasarkan pembahasan tersebut, maka kemampuan verbal yang dimiliki siswa memiliki kontribusi terhadap hasil belajar Bahasa Indonesia.

\section{Simpulan dan Saran}

Berdasarkan hasil dan pembahasan dapat disimpulkan bahwa, terdapat pengaruh yang signifikan pembelajaran berpendekatan saintifik berorientasi Cooperative, Integrated, Reading, And Composition (CIRC) terhadap hasil belajar bahasa Indonesia. Terdapat pengaruh yang signifikan pembelajaran berpendekatan saintifik berorientasi Cooperative, Integrated, Reading, And Composition (CIRC) dengan pengendalian kemampuan verbal terhadap hasil belajar bahasa Indonesia pada siswa kelas $\mathrm{V}$ di gugus I Kecamatan Jembrana tahun pelajaran 2018/2019. Terdapat kontribusi kemampuan verbal terhadap hasil belajar bahasa Indonesia siswa kelas V di gugus I Kecamatan Jembrana tahun pelajaran 2018/2019.

Berdasarkan simpulan di atas, dapat diberikan saran sebagai berikut. Siswa diharapkan dapat mengikuti pembelajaran dengan penerapan pendekatan pembelajaran untuk meningkatkan semangat belajarnya sehingga hasil belajar siswa meningkat. Selain itu siswa juga diharapkan dapat memperbanyak membaca untuk menambah kosakata agar kemampuan verbal meningkat, sehingga hasil belajar bahasa Indonesia juga meningkat. Guru diharapkan dapat menerapkan pendekatan pembelajaran inovatif sehingga dapat menarik minat siswa belajar dan tujuan pembelajaran dapat tercapai. Peneliti lain yang melakukan penelitian sejenis diharapkan dapat mengembangkan penelitian ini dengan menambah variabel atau menjadikan penelitian ini sebagai referensi penelitian berikutnya.

\section{Daftar Pustaka}

Agung, A. A. Gede. 2014. Metodologi Penelitian Pendidikan. Singaraja: Undiksha 2015. Statistik Inferensial. Singaraja: Undiksha

Dewi, Ni Kadek Trisna. 2013. "Pengaruh Implementasi Asesmen Portofolio Terhadap Kemampuan Menulis Dalam Bahasa Inggris Dengan Kovariabel Kemampuan Verbal Pada Siswa Kelas Xi IPB SMAN 1 Banjarangkan". Singaraja: Program Pascasarjana Universitas Pendidikan Ganesha.

Koyan, I Wayan. 2011. Asesmen dalam Pendidikan. Singaraja: Universitas Pendidikan Ganesha.

2012. Statistik Pendidikan Teknik Analisis Data Kuantitatif. Singaraja: Universitas Pendidikan Ganesha.

Mulyasa. 2013. Pengemangan dan Implementasi Kurikulum 2013. Bandung : PT Remaja Rosdakarya.

Musfiqon, HM. dan Nurdyansyah. 2015. Pendekatan Pembelajaran Saintifik. Sidoarjo : Nizamia Learning Center 
Kurniawan, Hardi. 2017. "Pengaruh Model Pembelajaran Kooperatif Tipe Circ (Cooperative Integrated Reading And Composition) Terhadap Kemampuan Membaca Kritis Teks Eksplanasi Siswa Kelas Vii Mts N 13 Jakarta Selatan". Jakarta: Uin Syarif Hidayatullah.

Ngalimun. 2016. Startegi dan Model Pembelajaran. Jogjakarta: Aswaja Pressindo.

Sugiartini, Ni Kt Ratna. 2013. "Pengaruh Model Pembelajaran Cooperative Integrated Reading And Composition (Circ) Terhadap Hasil Belajar Ips Kelas IV Gugus I Kecamatan Manggis".Volume 001.

Susanto, Ahmad. 2013. Teori Belajar Pembelajaran di Sekolah Dasar. Jakarta: PT Fajar Interpratama Mandiri.

Susanto, Joko. 2012. "Pengembangan Perangkat Pembelajaran Berbasis Lesson Study Dengan Kooperatif Tipe Numbered Heads Together Untuk Meningkatkan Aktivitas Dan Hasil Belajar IPA Di Sd". Semarang: Program Pascasarjana, Universitas Negeri Semarang.

Sumayasa, I N., A.A.I.N. Marhaeni, dan N. Dantes. 2015. "Pengaruh Implementasi Pendekatan Saintifik terhadap Motivasi Belajar dan Hasil Belajar Bahasa Indonesia pada Siswa Kelas VI di Sekolah Dasar Se Gugus VI Kecamatan Abang, Karangasem". E-Journal Program Pascasarjana Universitas Pendidikan Ganesha. Vol. 5, No.1. Tersedia pada http://oldpasca.undiksha.ac.id/e-journal/index.php/jurnal pendas/article/ view/1493. Diakses pada 8 Juni 2019.

Tristiantari, Ni Ketut Desia. 2016. "Model Pembelajaran Cooperatif Integrated Reading Composition Berpola Lesson Study Meningkatkan Keterampilan Membaca Dan Menulis". Volume 5. Nomor 2 (hlm. 204-206).

Undang-Undang Republik Indonesia Nomor 20 tahun 2003 tentang Sistem Pendidikan Nasional. Jakarta: Depdiknas.

Uno, Hamsah B, dan Nurdin Mohamad. 2011. Belajar Dengan Pendekatan PAIKEM. Jakarta: Bumi Aksara.

Pradnyani, Dyah Puspa Shinta. 2014. "Pengaruh Penerapan Asesmen Kinerja Terhadap Kemampuan Menulis Dalam Bahasa Jepang Dengan Kovariabel Kemampuan Verbal Pada Siswa Kelas Xii IPB Sma Negeri 1 Banjarangakan". e-Journal Program Pascasarjana Universitas Pendidikan Ganesha. Volume 4.

Widiani, T., M.Rifat, R.ljuddin. 2016. "Penerapan Pendekatan Saintifik dan Pengaruhnya terhadap Kemampuan Komunikasi Matematis dan Berpikir Kreatif Siswa". Jurnal Pendidikan dan Pembelajaran. Vol. 5, No.1. Tersedia pada http://jurnal.untan.ac.id/index.php/ipdpb/article/view/13550. Diakses pada 8 Juni 2019.

Yudiani, Ni Made. 2014. "Kontribusi Kemampuan Verbal Dan Kemampuan Membaca Pemahaman Terhadap Prestasi Belajar Siswa Dalam Menyelesaikan Soal Cerita Pada Pelajaran Matematika". Singaraja: Program Pascasarjana Universitas Pendidikan Ganesha. Volume 4. 